University of Wollongong

Research Online

Faculty of Engineering - Papers (Archive)

Faculty of Engineering and Information

Sciences

May 1997

\title{
Plane-strain modeling of smear effects associated with vertical drains
}

Buddhima Indraratna

University of Wollongong, indra@uow.edu.au

I. W. Redana

University of Wollongong

Follow this and additional works at: https://ro.uow.edu.au/engpapers

Part of the Engineering Commons

https://ro.uow.edu.au/engpapers/211

\section{Recommended Citation}

Indraratna, Buddhima and Redana, I. W.: Plane-strain modeling of smear effects associated with vertical drains 1997.

https://ro.uow.edu.au/engpapers/211

Research Online is the open access institutional repository for the University of Wollongong. For further information contact the UOW Library: research-pubs@uow.edu.au 


\title{
Plane-Strain Modeling of Smear Effects Associated with Vertical Drains
}

\author{
By B. Indraratna, ${ }^{1}$ Member, ASCE, and I. W. Redana ${ }^{2}$
}

\begin{abstract}
The present study provides a methodology to include the smear effect of vertical drains in a twodimensional (2D) plane-strain finite-element model, employing the modified Cam-clay theory. The analysis is conducted by converting the radius of the smear zone and its permeability (axisymmetric) into equivalent plane strain parameters. The introduction of smear effects improves the accuracy of the numerical model that is tested for a Malaysian soft clay, in this study.
\end{abstract}

\section{INTRODUCTION}

The large-scale production of prefabricated band drains is a result of the increasing popularity of installing vertical drains in soft ground, especially during the last two decades. The original axisymmetric analysis of vertical drains (Barron 1948) has been extended by Hansbo (1981) to include the effect of smear and well resistance. Hird et al. (1992) developed an equivalent plane-strain analysis considering a unit cell of the vertical drain, where geometric and permeability matching techniques were adopted. Although a further refinement of this method was reported later (Hird et al. 1995), the effect of smearing has not been incorporated in the plane-strain approach.

The main objective of this study is to develop an analytical model to quantify the smear effect, and to investigate its role on soft-clay behavior, using the finite-element method. Although the actual field conditions are three-dimensional (3D), an equivalent plane-strain model is often sufficient and advantageous with regard to the computational effort (Zeng and Xie 1989; Indraratna et al. 1994). The finite-element code, CRISP92 (Britto and Gunn 1987) has been extended to incorporate the current analytical model representing the smear effect.

\section{FUNDAMENTALS OF ANALYTICAL SOLUTION}

The flow of water into a vertical drain is axisymmetric in nature. Analytical modeling of radial flow to a central drain involves a cylinder of soil around a single vertical drain with simplified boundary conditions. In a two-dimensional (2D) finite-element analysis, in which the plane-strain model is used, it is necessary to convert the system of vertical drains into an equivalent drain wall (Fig. 1). Fig. 1(a) shows a unit cell with an external radius, $R$, and an initial length, $l$. The radius of the vertical drain and the smear zone are $r_{w}$ and $r_{s}$, respectively. According to Hansbo (1981), for axisymmetric flow, the average degree of consolidation $\bar{U}_{h}$ on a horizontal plane at a depth $z$ and at time $t$ may be predicted from

$$
\bar{U}_{h}=1-\exp \left(-\frac{8 T_{h}}{\mu}\right)
$$

where

1. $\mu=\ln (n / s)+\left(k_{h} / k_{h}^{\prime}\right) \ln (s)-0.75$ (smear effect only)

2. $\mu=\ln (n / s)+\left(k_{h} / k_{h}^{\prime}\right) \ln (s)-0.75+\pi z(2 l-z)\left[\left(k_{h}\right) /\right.$ $\left.\left(q_{w}\right)\right]$ (with both smear and well resistance)

'Sr. Lect., Dept. of Civil and Min. Engrg., Univ. of Wollongong, Northfields Ave., Wollongong, NSW 2522, Australia.

${ }^{2} \mathrm{PhD}$ Student, Dept. of Civ. and Min. Engrg., Univ. of Wollongong, Northfields Ave., Wollongong, NSW 2522, Australia.

Note. Discussion open until October 1, 1997. To extend the closing date one month, a written request must be filed with the ASCE Manager of Journals. The manuscript for this technical note was submitted for review and possible publication on August 1, 1996. This technical note is part of the Journal of Geotechnical and Geoenvironmental Engineering, Vol. 123, No. 5, May, 1997. CASCE, ISSN 1090-0241/97/0005$0474-0478 / \$ 4.00+\$ .50$ per page. Technical Note No. 13810 .
3. $\mu=\ln (n)-0.75$ (both smear and well resistance ignored)

In the preceding, $n=R / r_{w}$ and $s=r_{s} / r_{w}$ (also see Fig. 1); and $q_{w}=$ drain discharge capacity; $k_{h}=$ horizontal coefficient of permeability; and $k_{h}^{\prime}=$ horizontal coefficient of permeability in the smeared zone.

The vertical drain system may be converted into equivalent parallel drain walls by adjusting the spacing of the drain wall and the coefficient of permeability of the soil. In Fig. 1, the appropriate conversion was conducted by assuming the planestrain unit cell to have a width of $2 B$. The width of the drain may be determined by considering the total capacity of the drain in both systems to be the same. For example, in a system of vertical drains arranged at a spacing of $S$ in a square pattern, the width of the drain and the smear zone may be expressed by

$$
b_{w}=\frac{\pi r_{w}^{2}}{2 S} \text { and } b_{s}=\frac{\pi r_{s}^{2}}{2 S}
$$

For drains arranged in a triangular pattern, the equivalent widths are given by

$$
b_{w}=\frac{1.143 \pi r_{w}^{2}}{S} \text { and } b_{s}=\frac{1.143 \pi r_{s}^{2}}{S}
$$

where $S$ is the field spacing (center to center) between any two adjacent drains.

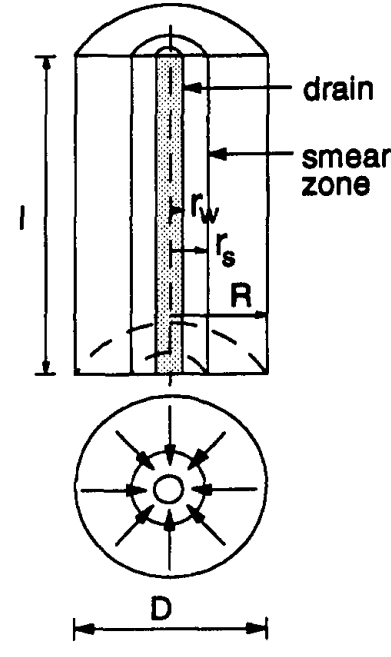

(a)

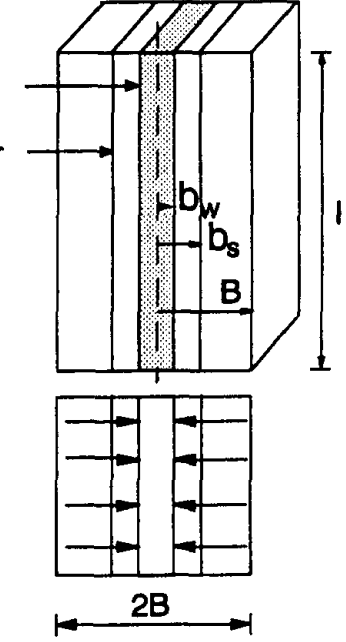

(b)
FIG. 1. Conversion of Axisymmetric Unit Cell into Plane Strain: (a) Axisymmetric Radial Flow; (b) Plane Strain 


\section{MODELING OF PLANE-STRAIN SOLUTION}

Axisymmetric analysis described by Hansbo (1981) may be transformed to an equivalent plain-strain solution as follows. Considering Darcy's law, the velocity of water flow $\left(v_{x}\right)$ in the undisturbed zone is given by the following equation:

$$
v_{x}=\left(\frac{k_{h p}}{\gamma_{w}}\right)\left(\frac{\partial u}{\partial x}\right)
$$

where $k_{h p}=$ coefficient of horizontal permeability, where the subscript $p$ represents the plane strain condition; $\gamma_{w}=$ unit weight of water, $u=$ pore water pressure, and $x=$ prescribed direction of flow. In the smear zone, the corresponding relation for flow in the same direction is assumed to be governed by

$$
v_{x}=\left(\frac{k_{h p}^{\prime}}{\gamma_{w}}\right)\left(\frac{\partial u^{\prime}}{\partial x}\right)
$$

where $k_{h p}^{\prime}$ and $u^{\prime}$ are the coefficient of permeability and pore water pressure in the smeared zone, respectively.

For the plane-strain model, consider a horizontal slice of thickness $d z$, as shown in Fig. 2, for the unit cell. It is postulated that the flow in the slice at a distance $x$ from the centerline of the drain is equal to the change in volume within a block of soil of width $(B-x)$, such that

$$
v_{x}=\left(\frac{\partial \varepsilon}{\partial t}\right)(B-x)
$$

where $\varepsilon$ is the strain in the $z$ direction. Substituting (3) into (5) and rearranging them gives the following equation for the pore pressure gradient in the undisturbed soil domain outside the smeared zone:

$$
\left(\frac{\partial u}{\partial x}\right)=\left(\frac{\gamma_{w}}{k_{h p}}\right)\left(\frac{\partial \varepsilon}{\partial t}\right)(B-x) ; \quad B \geq x \geq b_{s}
$$

In the smeared (disturbed) zone, the corresponding pore pressure gradient is then given by

$$
\left(\frac{\partial u^{\prime}}{\partial x}\right)=\left(\frac{\gamma_{w}}{k_{h p}^{\prime}}\right)\left(\frac{\partial \varepsilon}{\partial t}\right)(B-x) ; \quad b_{s} \geq x \geq b_{w}
$$

For vertical flow in the $z$ direction of the drain, the change of flow from the entrance to the exit of the slice $d q_{z}$ is given by

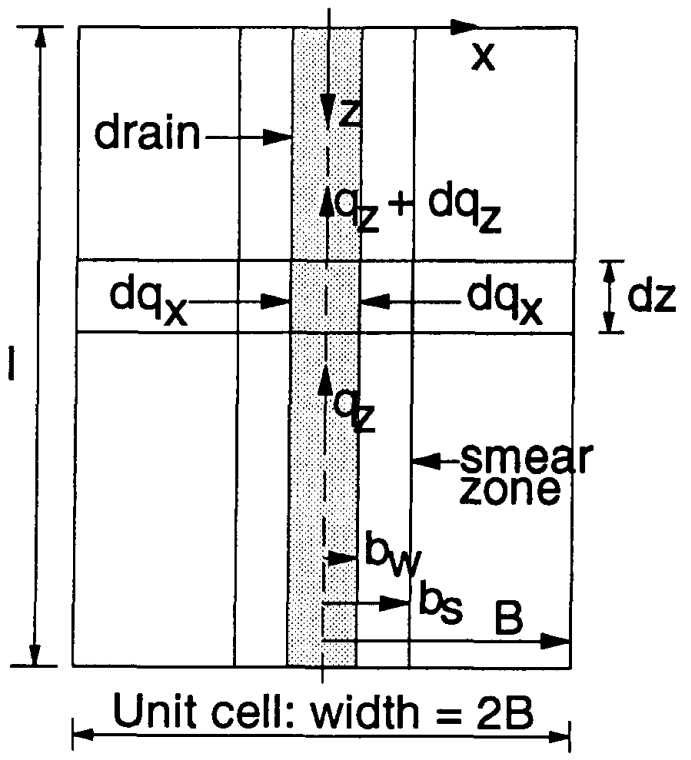

FIG. 2. Plane Strain Unit Cell

$$
d q_{z}=\left(\frac{q_{z}}{\gamma_{w}}\right)\left(\frac{\partial^{2} u}{\partial z^{2}}\right)_{x \leq b_{w}} d z d t
$$

The horizontal inflow to the drain slice from each side $d q_{x}$ is determined from

$$
d q_{x}=\left(\frac{k_{h p}}{\gamma_{w}}\right)\left(\frac{\partial u}{\partial z}\right)_{x=b_{w}} d z d t
$$

For ensuring continuity of flow, the following equation needs to be satisfied (Fig. 2):

$$
d q_{z}+2 d q_{x}=0
$$

It is assumed that at the boundary of the drain $\left(x=b_{w}\right)$ there is no sudden drop in pore pressure, hence, $u=u^{\prime}$. Substituting (8) and (9) in (10) and subsequent rearranging with the above boundary condition yields

$$
\left(\frac{\partial u^{\prime}}{\partial x}\right)_{x=b_{w}}+\frac{q_{z}}{2 k_{h p}}\left(\frac{\partial^{2} u^{\prime}}{\partial z^{2}}\right)_{x=b_{w}}=0
$$

Substituting (11) into (7) and integrating in the $z$ direction subject to the following boundary conditions: at $z=0, u^{\prime}=0$; at $z=2 l, u^{\prime}=0$; and at $z=l, \partial u^{\prime} / \partial z=0$, the pore pressure in the smeared zone $u^{\prime}$ may be determined by

$$
\left(u^{\prime}\right)_{x=b_{w}}=\frac{2 B \gamma_{w}}{q_{2}}\left(\frac{k_{h p}}{k_{h p}^{\prime}}\right) \frac{\partial \varepsilon}{\partial t}\left(l z-\frac{z^{2}}{2}\right)
$$

Integrating (6) and (7) in the $x$ direction with the same boundary conditions as stated previously, and by assuming $u=u^{\prime}$ at the interface $x=b_{s}$ (see Fig. 2), gives the following two expressions for $u$ and $u^{\prime}$ :

$$
u=\frac{\gamma_{w}}{2} \frac{\partial \varepsilon}{\partial t} \frac{1}{k_{h p}}\left[x(2 B-x)+\frac{2 B}{q_{z}} \frac{k_{h p}^{2}}{k_{h p}^{\prime}}\left(2 l z-z^{2}\right)-b_{s}\left(2 B+b_{s}\right)\right]
$$

$u^{\prime}=\frac{\gamma_{w}}{2} \frac{\partial \varepsilon}{\partial t} \frac{1}{k_{h p}^{\prime}}\left[x(2 B-x)+\frac{2 B k_{h p}}{q_{z}}\left(2 l z-z^{2}\right)-b_{w}\left(2 B-b_{w}\right)\right]$

Let $\vec{u}$ be the average excess pore water pressure between the smeared and intact zones, at depth $z$ and for a given time, $t$

$$
\bar{u}=\frac{\int_{b_{s}}^{B} u d x+\int_{b_{w}}^{b_{s}} u^{\prime} d x}{B}
$$

The solution of (15) by substitution from (13) and (14) gives the following expression for the average excess pore water pressure at any given depth, $z$, and time, $t$.

$$
\begin{gathered}
\bar{u}=\frac{B^{2} \gamma_{w}}{2 k} \frac{\partial \varepsilon}{\partial t}\left[\alpha+\frac{k_{h p}}{k_{h p}^{\prime}}(\beta)+(\theta)\left(2 l z-z^{2}\right)\right] \\
\text { where } \alpha=\frac{2}{3}-\frac{4 b_{s}^{3}}{3 B^{3}}+\frac{2 b_{s}^{2}}{B^{2}}-\frac{2 b_{s}}{B} \\
\beta=\frac{b_{s}^{2}}{B}-\frac{b_{s}^{3}}{3 B^{3}}-\frac{2 b_{w}^{3}}{3 B^{3}}-\frac{2 b_{w} b_{s}}{B^{2}}+\frac{b_{w}^{2}}{B^{2}}+\frac{b_{w}^{2} b_{s}}{B^{3}} \text { and } \\
\theta=\frac{2 k_{h p}^{2}}{B q_{z}}-\frac{2 b_{w} k_{h p}^{2}}{B^{2} q_{z}}
\end{gathered}
$$

Eq. (16) may now be combined with the time-dependent compressibility governed by the following well-known consolidation expression: 


$$
\frac{\partial \varepsilon}{\partial t}=-m_{v} \frac{\partial \bar{u}}{\partial t}=\frac{k_{h p}}{c_{h p} \gamma_{w}} \cdot \frac{\partial \bar{u}}{\partial t}
$$

where $m_{v}=$ coefficient of volume compressibility and $c_{h p}=$ horizontal coefficient of consolidation. Substituting (17) into (16), and then integrating, subject to the boundary condition that at $t=0, \bar{u}=\bar{u}_{0}$ gives the following expression:

$$
t=-\frac{B^{2} \gamma_{w} m_{v}}{2 k_{h p}} \mu_{p} \ln \left(\frac{\bar{u}}{\bar{u}_{0}}\right)
$$

where $\mu_{p}=\left\{\alpha+(\beta)\left[\left(k_{h p}\right) /\left(k_{h p}^{\prime}\right)\right]+(\theta)\left(2 l z-z^{2}\right)\right\}$. Clearly the term $\left(\bar{u} / \bar{u}_{0}\right)$ in $(18)$ is directly related to the average degree of consolidation $\left(\bar{U}_{h p}\right)$ and the time factor $\left(T_{h p}\right)$ for plane-strain conditions, represented by

$$
\bar{U}_{h p}=1-\frac{\bar{u}}{\bar{u}_{0}}=1-\exp \left(\frac{-8 T_{h p}}{\mu_{p}}\right)
$$

At each time step and at a given stress level, the average degree of consolidation for both axisymmetric $\left(\vec{U}_{h}\right)$ and equivalent plane strain $\left(\bar{U}_{h p}\right)$ conditions are made equal, hence:

$$
\bar{U}_{h}=\bar{U}_{h p}
$$

A combination of (19) and (20) with the original Hansbo (1981) theory (1), defines the time factor ratio by the following equation:

$$
\frac{T_{h p}}{T_{h}}=\frac{k_{h p}}{k_{h}} \cdot \frac{R^{2}}{B^{2}}=\frac{\mu_{p}}{\mu}
$$

For a square and triangular patterns of vertical drains, the diameter of influence for each drain $(D=2 R)$ is given by $D=$ $1.13 S$, and $D=1.05 S$, respectively (Barron 1948). In the equivalent plane-strain model, the spacing $S$ is equal to the total width of the unit cell, $2 B$. Therefore, for simplicity, the writers have assumed the magnitudes of $R$ and $B$ to be the same, which results in the following expression for the equivalent plane strain permeability:

$$
k_{h p}=\frac{k_{h}\left[\alpha+(\beta) \frac{k_{h p}}{k_{h p}^{\prime}}+(\theta)\left(2 l z-z^{2}\right)\right]}{\left[\ln \left(\frac{n}{s}\right)+\left(\frac{k_{h}}{k_{h}^{\prime}}\right) \ln (s)-0.75+\pi\left(2 l z-z^{2}\right) \frac{k_{h}}{q_{w}}\right]}
$$

Ignoring the well resistance in (22), where all terms containing $l$ and $z$ are omitted, the influence of the smear effect can be isolated and represented by the ratio of the smear zone permeability to the undisturbed permeability as follows:

$$
\frac{k_{h p}^{\prime}}{k_{h p}}=\frac{\beta}{\left[\ln \left(\frac{n}{s}\right)+\left(\frac{k_{h}}{k_{h}^{\prime}}\right) \ln (s)-0.75-\alpha\right]}
$$

The influence of well resistance is not pronounced when significant flows $\left(q_{w}\right.$ and $\left.q_{z}\right)$ take place within the drains, whereby the parameter $\theta$ becomes small in comparison with the smear effect terms. If both smear and well resistance effects are ignored, then the simplified ratio of plane strain to axisymmetric permeability is readily obtained, as proposed earlier by Hird et al. (1992)

$$
\frac{k_{h p}}{k_{h}}=\frac{0.67}{[\ln (n)-0.75]}
$$

In this study, both (23) and (24) are incorporated in the numerical analysis employing CRISP92 to analyze a case history as discussed in the proceeding section.

\section{APPLICATION OF MODEL TO CASE HISTORY}

The validity of the mathematical model was examined in relation to the performance of an embankment stabilized with vertical drains on soft Muar clay in Malaysia (Indraratna et al. 1994). Fig. 3 shows the cross section of the embankment, the subsoil profile, and the prefabricated vertical drains (mandrel driven) installed in a triangular pattern at a spacing of $1.30 \mathrm{~m}$. The equivalent drain diameter, the diameter of the axisymmetric influence zone for each drain, and the extent of the smear zone were estimated to be $70 \mathrm{~mm}, 1.365 \mathrm{~m}$, and $0.4 \mathrm{~m}$, respectively, according to Hansbo (1981). For the triangular pattern of vertical drains, the equivalent width of the drain and smear zone were calculated using $(2 b)$ to give $b_{w}=0.34 \mathrm{~cm}$ and $b_{s}=11 \mathrm{~cm}$, respectively.

The embankment (86-m wide), composed of compacted sandy clay, has a unit weight of $20.5 \mathrm{kN} / \mathrm{m}^{3}$. During the first stage of construction, the embankment was raised to a height of $2.57 \mathrm{~m}$ in $14 \mathrm{~d}$. Following a rest period of $105 \mathrm{~d}$, an additional fill was placed (the second stage) until the embankment reached a height of $4.74 \mathrm{~m}$ in $24 \mathrm{~d}$. The settlements and excess pore water pressures were monitored for about $400 \mathrm{~d}$.

The numerical analysis was based on the modified Camclay model (Roscoe and Burland 1968) incorporated in the finite-element code, CRISP92. The Cam-clay parameters for each soil layer (Table 1) include the gradients of volume against log-pressure relations for consolidation and swelling ( $\lambda$ and $\kappa$, respectively), slope of the critical state line based on effective stress $(M)$, void ratio on critical state line (CSL) at unit normal effective pressure $\left(e_{c s}\right)$, Poisson's ratio $(\nu)$, shear

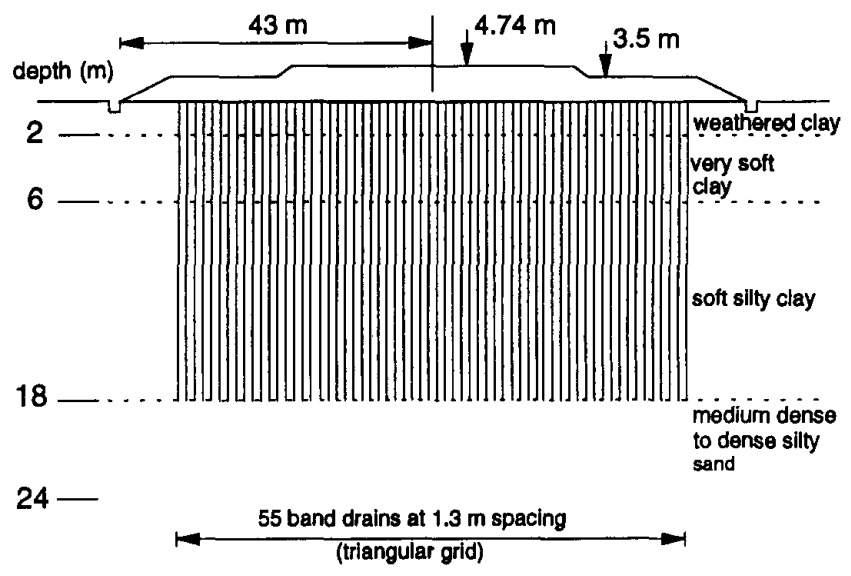

FIG. 3. Cross Section through Centerline of Embankment with Subsoil Profile

TABLE 1. Cam-Clay Parameters Used in Numerical Analysis

\begin{tabular}{c|c|c|c|c|c|c}
\hline \hline $\begin{array}{c}\text { Depth } \\
(\mathrm{m})\end{array}$ & $\kappa$ & $\lambda$ & $\theta_{c s}$ & $M$ & $\nu$ & $\gamma_{\text {。 }}\left(\mathrm{kN} / \mathrm{m}^{3}\right)$ \\
$(1)$ & $(2)$ & $(3)$ & $(4)$ & $(5)$ & $(6)$ & $(7)$ \\
\hline $0-1.75$ & 0.06 & 0.16 & 3.10 & 1.19 & 0.29 & 16.5 \\
$1.75-5.50$ & 0.06 & 0.16 & 3.10 & 1.19 & 0.31 & 15.0 \\
$5.50-8.0$ & 0.05 & 0.13 & 3.06 & 1.12 & 0.29 & 15.5 \\
$8.0-18.0$ & 0.035 & 0.09 & 1.61 & 1.07 & 0.26 & 16.0 \\
\hline \hline
\end{tabular}

TABLE 2. Coefficients of Permeability Used in Numerical Analysis

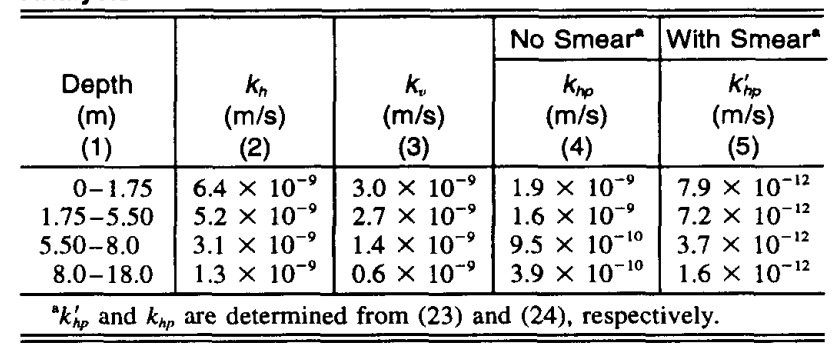

476 / JOURNAL OF GEOTECHNICAL AND GEOENVIRONMENTAL ENGINEERING / MAY 1997 
modulus $(G)$, and the saturated unit weight of soil $\left(\gamma_{s}\right)$. To estimate the undisturbed soil permeability, laboratory consolidation tests were conducted on both vertically and horizontally oriented specimens. In the smear zone, the horizontal permeability was assumed to be equal to the vertical permeability. The measured horizontal and vertical permeability coefficients of the undisturbed soil $\left(k_{h}\right.$ and $\left.k_{v}\right)$ and the equivalent plane-strain values based on (28) and (29) are given in Table 2.

The discretized finite-element mesh near the drain boundary is shown in Fig. 4, which contains six-node linear-strain triangular (LST) elements with three pore-pressure nodes. Because of symmetry, it is sufficient to consider one half of the unit cell. The clay layer is characterized by drained conditions at both the upper and lower boundaries. The embankment loading was simulated by applying incremental vertical loads to the upper boundary. The excess pore-water pressures were set to zero along the drain boundary to simulate complete dissipation. The effect of well resistance was neglected, and (23) was employed to model the effect of smearing.

The results of the plane-strain analysis together with the measured settlements are plotted in Fig. 5(a). As expected, the analysis based on perfect drain conditions (no smear, complete pore pressure dissipation) overpredicts the measured settlement, whereas the inclusion of smear effect significantly improves the accuracy of the predictions. An excellent match is obtained if the permeability of the smear zone is arbitrarily increased by a factor of 2.5-3.0 for all subsoil layers. This is not surprising because the permeability in the field can often be larger than that of small laboratory specimens due to ground anisotropy, natural fissures, etc. The predicted and measured excess pore-water pressures under the centerline of the embankment at depths of $9.1 \mathrm{~m}$ and $13.6 \mathrm{~m}$ below the ground surface are compared in Fig. 5(b). The pore pressure increase during loading in the first stage is well predicted, but the postconstruction predictions (after loading in the second stage) indicate a greater rate of pore-pressure dissipation in comparison with the gradually decreasing field data. This retarded

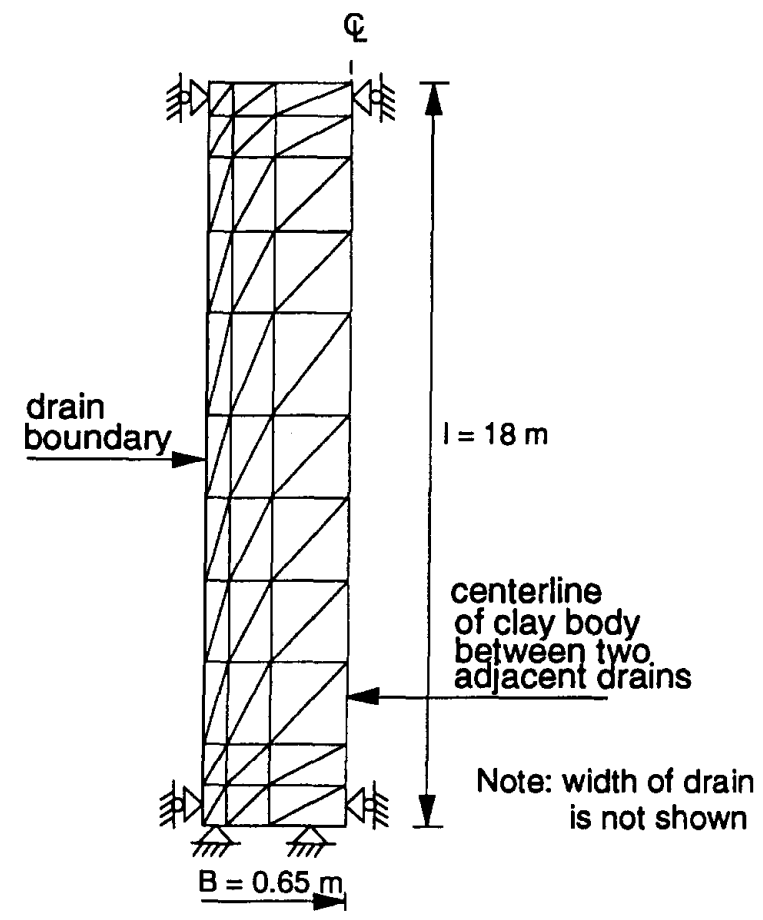

FIG. 4. Finite-element Mesh in Vicinity of Drain

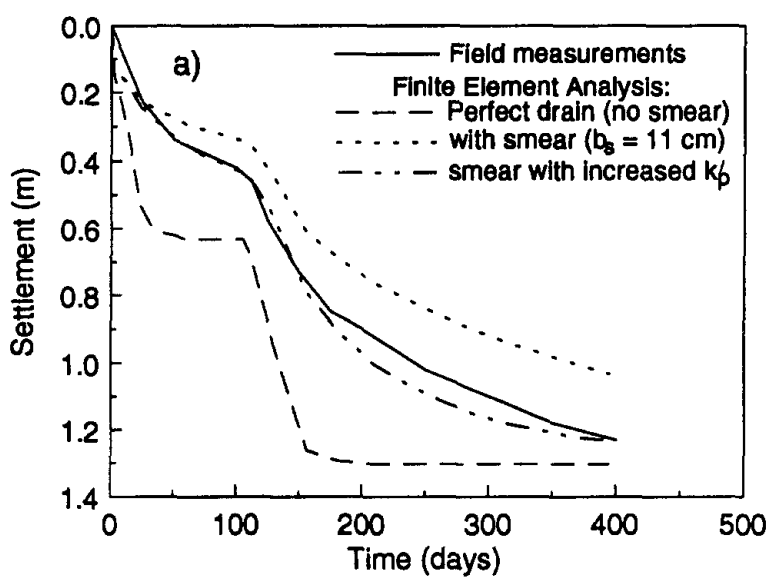

(a)

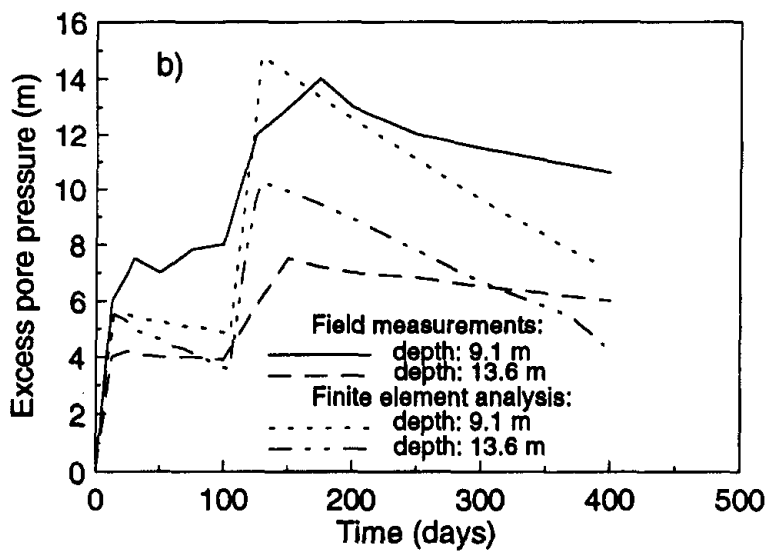

(b)

FIG. 5. (a) Consolidation Settlement at Ground Surface of Embankment Center; (b) Variation of Excess Pore Water Pressures at Embankment Centerline for Plezometer at $9.1 \mathrm{~m}$ and $13.6 \mathrm{~m}$ below Ground Level

pore-pressure dissipation in the field has been attributed to the probability that a significant proportion of drains became partially clogged (Ratnayake 1991; Indraratna and Balasubramaniam 1995).

\section{CONCLUSION}

In this study, a mathematical formulation has been introduced to transform the actual axisymmetric conditions to an equivalent 2D plane-strain model, incorporating the smear effect associated with mandrel-driven vertical drains. In this procedure, the width of the unit cell is taken to be the same as the spacing between the drains, whereas the width of the smear zone and the permeability of the smeared soil are converted theoretically into equivalent plane-strain parameters. The validity of the method has been examined by analyzing an embankment built on soft clay stabilized with vertical drains. The introduction of smear effects improves the accuracy of settlement predictions based on the equivalent plane-strain analysis. However, the postconstruction pore-pressure dissipation in the field is more gradual in comparison with the finite-element predictions.

\section{APPENDIX. REFERENCES}

Barron, R. A. (1948). "Consolidation of fine-grained soils by drain wells." Trans., ASCE, New York, N.Y., 113, 718-742. 
Britto, A. M., and Gunn, M. J. (1987). Critical state soil mechanics via finite elements. Ellis Horwood, Ltd., Chichester, England.

Hansbo, S. (1981). "Consolidation of fine-grained soils by prefabricated drains." Proc., JOth Int. Conf. on Soil Mech. and Found. Engrg., Publications Committee of ICSMFE, ed., A. A. Balkema, Rotterdam, The Netherlands, 677-682.

Hird, C. C. Pyrah I C and Russell, D. (1992) "Finite element modelling of vertical drains beneath embankments on soft ground." Geotechnique, London, U.K., 42(3), 499-511.

Hird, C. C., Pyrah, I. C., Russell, D., and Cinicioglu, F. (1995). "Modeling the effect of vertical drains in two-dimensional finite element analyses of embankments on soft ground." Can. Geotech. J., Ottawa, Canada, 32(5), 795-807.

Indraratna, B., Balasubramaniam, A. S., and Ratnayake, P. (1994). "Performance of embankment stabilized with vertical drains on soft clay." J. Geotech. Engrg. Div., ASCE, 120(2), 257-273.
Indraratna, B., and Balasubramaniam, A. S. (1995). "'Consolidation of soft marine clay foundations under embankment loading." Proc., Int Symp., Compression and Consolidation of Clayey Soils, H. Yoshikuni and O. Kusakabe, eds., A. A. Balkema, Rotterdam, The Netherlands, $683-688$.

Ratnayake, A. M. P. (1991). "Performance of test embankments with and without vertical drains at Muar Flats site, Malaysia," ME thesis, Asian Institute of Technology, Bangkok, Thailand.

Roscoe, K. H., and Burland, J. B. (1968). "On the generalized stress strain behavior of wet clay." Engineering plasticity, J. Heyman and F. A. Leckie, eds., Cambridge University Press, Cambridge, U.K., 535609

Zeng, G. X., and Xie, K. H. (1989). "New development of the vertical drain theories." Proc., 12th Int. Conf., Soil Mech. and Found. Engrg. Publications Committee of ICSMFE, ed., A. A. Balkema, Rotterdam, The Netherlands, 1435-1438. 